\title{
DEBATES
}

\section{Os dificeis ecos dos direitos humanos: participação e cultura entre as gerações}

\author{
The intricate echoes of human rights: participation and culture \\ between generations
}

\section{Solon Eduardo Annes Viola Thiago Vieira Pires}

\section{Resumo}

A juventude, de tempos em tempos, ocupa espaços nos cenários políticos e nas ruas das cidades anunciando desejos e buscando direitos. Suas participaçóes inquietam os governos e deslocam as possíveis verdades que as ciências sociais pensam ter encontrado em cada uma de suas vertentes teóricas. A presença dos movimentos estudantis de 1968, colocou em dúvidas as variáveis críticas, e outras nem tanto, dos séculos XIX e da primeira metade do século XX. As manifestaçóes do século XXI, intensificadas no ano de 2013, anuncia, outra vez, a urgência da revisão das teorias estabelecidas. Agora, como antes, discute-se a participação dos jovens. Agora, como antes, a participação da juventude nos movimentos sociais expressa em seu conteúdo o desejo, nem sempre expresso claramente, de construir uma cultura dos direitos humanos. Este texto busca aproximar a participação da juventude nos dois períodos históricos referidos, procurando destacar a presença dos direitos humanos ora como possibilidade, ora como carências.

\section{Palavras-chave}

Juventude; Participação; Cultura; Direitos Humanos; Democracia.

\begin{abstract}
The youth, periodically, occupies spaces in political sceneries and in the city streets announcing its desires and appealing for its rights. Young people's participation disquiets governments and dislocates possible truths that the Social Sciences believe to have found in each one of its theoretical divisions. The emergence of student's movements of 1968 has put in doubt critical variables, and others not as much, of XIX century and of the first half of XX century. The XXI century manifestations, intensified in 2013, announce the urgency in the revision of established theories. Now, as before, youth participation is questioned. Now, as before, the youth participation in social movements express in its content the desire, not always clearly expressed, of building a human rights culture. This article seeks to approximate youth participation in the two historical periods referred, trying to highlight the human rights presence in each of them, sometimes as a possibility, sometimes as a deficiency.
\end{abstract}

\section{Keywords}

Youth; Participation; Culture; Human Rights; Democracy. 


\section{Introdução}

As ruas das cidades brasileiras têm sido de espaço para uma multiplicidade de cores, cartazes e vozes que anunciam a descoberta de novas possibilidades de participação. Porém, este é um anúncio que já foi feito nas décadas de 1960 e 1970 em terras de Pindorama, ele se materializa na forma de uma utopia contemporânea que poderá vir a ser chamada cultura de direitos humanos.

Desnecessário relembrar que entre os cantos e as falas dos jovens - das duas geraçôes - a clamar por direitos, é possível ouvir ruídos intensos. De um lado, vozes e cartazes em busca de direitos, de outro, corpos protegidos e armas em busca de silenciamentos. Entre eles, uma mídia hegemônica às vezes indefinida às vezes escusa e disposta a repetir manchetes e pré-conceitos formados desde há muito tempo. Nas manifestações recentes, ao contrário das do século passado, já se pode encontrar formas alternativas de mídia que conseguem produzir contrainformação.

A busca por uma cultura de direitos humanos pode se tornar uma das pontes que aproxima o tempo de geraçóes - juvenis, mas não só juvenis - em busca de participação e cidadania, ainda tão distante da plenitude exigida para a consolidação de uma democracia política e social. Mas, se esta ponte une os movimentos de participação social outra ponte, a dos cassetes, das proibições dos inquéritos forjados e das notícias pré-concebidas, unem o passado e o presente com o anúncio de que o passado ainda é presente, mesmo quando travestido pelas tecnologias multicoloridas da mídia eletrônica ou mesmo com fardamentos robocópicos dos aparelhos de coerção social. O velho, intransigente e ciente do que precisa preservar, move-se quase sem a possibilidade de consenso - para impedir que a ousadia dos jovens percorra os caminhos, que sua utopia contemporânea anuncia teimosamente.

A utopia dos direitos humanos possui a polissemia de sua contemporaneidade. Tornou-se tema importante no início da década de 1960 como bandeira da civilização e uma provável defesa da democracia ocidental em guarida radical às diferentes formas de opressão que tentavam frear o processo em busca de igualitarismo social e político que de diferentes formas anunciavam outros caminhos para a humanidade naquele período histórico.

Múltiplos e plurais, os direitos humanos eram então anunciados de como um sonho equivalente ao do modo de vida estadunidense, colocado à disposição da sociedade latino-americana como um convite à liberdade de mercado, ao acesso às inovações tecnológicas, aos agitados movimentos das danças folks, ao sabor adocicado das colas geladas e às cores fascinantes das novelas globais.

Os anúncios dos direitos humanos - para além das maravilhas propagandeadas - traziam embutido um sistema de poder que protegia a si mesmo 
enquanto usurpava não só os direitos civis e políticos e as identidades latinoamericanas, como também a integridade da cidadania e dos cidadãos. Oferecidos como forma possível de consenso entre os povos latino-americanos do centro e do sul, os direitos humanos serviram de pano de fundo sob o qual não foram infringidos somente os direitos culturais, mas, sobretudo, o direito maior à vida.

O direito à vida foi ameaçado pela violência comandado pela coerção, pela prática continuada da tortura, pelo poder das armas e pela morte com o qual os regimes militares salvaguardavam seus privilégios. $O$ controle dos meios de comunicação através da censura e da publicidade oficial buscava garantir a propagação do pensamento único como forma de conseguir apoio junto a setores da população.

As práticas políticas não violentaram somente a cultura dos direitos humanos, ao contrário, atingiram todo o universo cultural e político e os limites da racionalidade humana. Quando a sociedade conseguiu encontrar espaços de reorganização - em um sistema que se deteriorava tanto no controle do Estado quanto na manutenção da hierarquia no interior das forças armadas - os direitos humanos ressurgiram como proposta plural, não mais civilizatória, abrigando movimentos múltiplos que não se limitavam aos direitos civis e políticos típicos $\mathrm{da}$ democracia representativa, mas anunciavam reivindicações direitos sociais e econômicos.

Os pressupostos dos direitos humanos ressurgiam para recusar as violências do Estado e para anunciar uma nova utopia que pretendia, sem esquecer o passado, descobrir um caminho entre aquele presente e um futuro que contivesse um ideário no qual as liberdades civis e políticas fossem amparadas pela igualdade social e jurídica, resguardada por uma economia baseada na solidariedade e ambientalmente responsável. Com estas bandeiras a utopia dos anos 1980 foi capaz de reunir a sociedade civil e colocá-la em movimento.

As denúncias dos crimes cometidos contra os inimigos do regime, feitas a meia-luz e nas conversas de pé de ouvido, ganhavam corpo enquanto a coerção do aparelho repressivo e a publicidade oficial não conseguiam mais conter a participação social. Refeito, o movimento e a sociedade moviam-se em busca do fim da censura, do fim da tortura, da anistia ampla geral e irrestrita, das eleições diretas e da constituinte livre e soberana.

Ao lado destes movimentos por direitos civis e políticos, e como elemento "novo" na vida nacional, surgiram outras ações em busca de reforma agrária, de moradia e de melhorias urbanas, em defesa do meio ambiente - os direitos sociais e 
econômicos - e outros mais anunciando o anseio de uma sociedade sem preconceitos em busca do reconhecimento das diferenças.

Refeito dos discursos salvacionistas do início dos anos 1960 os direitos humanos ressurgiam como uma crítica contundente do regime autoritário. Abandonando a aura civilizatória, apontavam os crimes e os privilégios dos regimes de exceção e, movendo um amplo universo de forças sociais, denunciava as estruturas políticas e econômicas dos anos 1980 pretendendo ter vigor para ampliar os processos de participação política.

A passagem das ditaduras latino-americanas para a democracia revelou-se um período de mobilizaçáo social com manifestações por questóes culturais - que envolviam direitos civis e políticos - mas, também, questóes materiais incorporando históricas reivindicações de igualdade social e respeito às diferenças. Já as questóes culturais incorporaram as lutas por direitos pressupostos ligados à condição humana mais essencial, como a busca por mortos e desaparecidos, a defesa intransigente da recuperação da memória, a reconstituição da verdade e o restabelecimento - mesmo que tardio - da justiça.

O trânsito do autoritarismo para a democracia representativa - recorde-se que o movimento pelas diretas-já resultou na eleição indireta para o primeiro presidente civil oriundo das correntes oposicionistas - manteve-se, disciplinadamente, nos limites da transição lenta e gradual elaborada nos gabinetes estratégicos do poder militar. Mesmo imersa por essa conjuntura de poder a sociedade civil, com participação das gerações jovens, se mantinha mobilizada na busca de maiores espaços de influência, como na busca de uma assembleia constituinte soberana, nas manifestaçóes contra a carestia e nas propostas pelo fim do então chamado "entulho autoritário". Entre estes o Estado nacional preservou o aparelho repressivo, uma versão distorcida da história, enquanto sonegava a verdade para os educandos - em sua maioria jovem - dos diferentes níveis de ensino. Não foi capaz, também, de rever um modelo de anistia que impedia a ação da justiça e, acima de tudo, garantir a liberdade para agentes do Estado que cometeram crimes contra a humanidade e por não terem sido julgados, produziram uma cultura de impunidade para os atuais agentes de segurança.

Este texto tem como eixo recompor o processo de formação de uma cultura de participação construída a partir dos direitos humanos. Procura traçar um paralelo entre duas geraçóes e suas histórias de enfrentamentos. A primeira a que alterou o significado dos direitos humanos transformando-os de um projeto civilizador para uma proposta de cultura emancipatória a partir da luta por direitos civis e políticos, dos conflitos de libertação no entáo chamado terceiro mundo, nos movimentos pela 
paz e nas afirmaçóes do movimento feminista. A segunda, aquela que agora se movimenta em busca de direitos sociais e econômicos, bem como da ampliação dos direitos políticos, especialmente àqueles da democracia representativa e da democracia participativa.

\section{Direitos Humanos e Democratização}

A geraçáo dos anos 1960 e 1970 viveu sua experiência juvenil em um contexto cultural de transformaçóes estéticas que alteravam elementos como: os ritmos musicais (desde os novos sons do rock, às cançôes de protesto da América Latina), as perspectivas da arte cinematográfica (desde as transformações do cinema francês e italiano ao cinema novo brasileiro) e as transformaçôes da moda (com a minissaia das jovens europeias, os cabelos longos das bandas inglesas e dos jovens hippies). A geração deste período viveria experiências capazes de alterar os padróes culturais, entre os quais, a compreensão que os jovens são, também, sujeitos de direitos.

Foi comum para os jovens, daquele período, percorrer um difícil caminho para chegar à vida adulta. A juventude europeia compreendera, desde Nantes e de Paris, que os anos de ouro do capitalismo de pós-guerra haviam chegado a seu limite e que o futuro não era mais de expansão interminável. Bourdieu e Passeron (1975) haviam demonstrado que o sistema de ensino reproduzia a sociedade conservadora, e seus privilégios deixando estreitas margens para a transformação social. A rebelião dos jovens indicava o desejo de assumir o controle de suas vidas.

Para a sociedade de então se tornava evidente, também, que o fim da Guerra de 1945 não significava a paz prometida pela Organização das Naçóes Unidas, e que os conflitos coloniais continuariam a consumir a vida dos jovens europeus e estadunidenses em guerras nas antigas colônias da África e do Extremo Oriente especialmente no Vietnã, no Laos e Camboja.

Os muros das universidades francesas anunciavam desejos que percorreram a Europa e ecoaram nas Universidades estadunidenses e canadenses. Moveram-se em direção ao Leste europeu reivindicando liberdades individuais e participação nas questôes do Estado. Na Itália e na Alemanha, mais do que nos outros países, a radicalização levou a formação de grupos de guerrilha urbana dispostos transformar o mundo pelas armas, caso específico das Brigadas Vermelhas e do Grupo BaaderMainhof. De qualquer modo, os movimentos anunciavam o anseio de paz e o início de um tempo de amorosidades (Faça Amor náo Faça a Guerra - palavra de ordem hippie que no norte da América exigia o fim Guerra do Vietnã). Os jovens da Sorbonne escreviam nos muros da Universidade que era preciso exigir o impossível. 
A juventude da América Latina moveu-se não só na dimensão da utopia que carregava consigo os desejos de liberdade (ADORNO, 2010) de seus contemporâneos do entáo chamado Primeiro Mundo. No hemisfério sul da América, mas também no México e no Caribe, para os jovens não bastava caminhar "sem lenço e sem documento" (VELOSO, 1966). Tornava-se indispensável romper as barreiras culturais e sociais da época, romper os preconceitos de uma sociedade de privilégios, lançar as bases de uma democracia estável e de uma cidadania que superasse as heranças autoritárias e os regimes ilegais que assumiam o controle dos Estados através de golpes de força militar. Golpes que mantinham sobre o continente uma noite sem fim.

O inédito nos golpes da América Latina da segunda metade do século XX é que estes ocorreram sob a hegemonia da Doutrina de Segurança Nacional (DSN) que hegemonizava a diplomacia estadunidense da Guerra Fria e reinventava o maniqueísmo político que as revoluçóes do século XVIII pretendiam superar. A partir de então o "triunfo do bem" (o livre mercado) seria buscado sem limites. Para conter "o mal” (as alternativas socialistas) tudo seria legítimo - mesmo que fosse necessário mudar a lei - inclusive violar os direitos humanos e conter a democracia e seus pressupostos de liberdade e igualdade. A ordem era não temer o preço da violência e os crimes contra a humanidade (CHOMSKY, 2003).

Os golpes militares assumiram, sem necessidade de justificativa política, uma razão de ser. Seus atos estavam referendados por uma teoria, a Doutrina de Segurança Nacional (DSN), e reconhecidos como indispensáveis para a manutenção da civilização ocidental e a consolidação da hegemonia do grande capital industrial e financeiro internacional. Tinham por objetivo fortalecer um modelo de desenvolvimento hegemonizado pelo capital internacional e servir de experiência às políticas econômicas propostas pela Universidade de Chicago, especialmente no caso da ditadura militar do Chile. Entre os efeitos mais duradouros destas políticas estão o rápido processo de urbanização sem planejamento, a coerçáo aos sindicatos (acompanhada pelo arrocho dos salários dos trabalhadores urbanos) e aos movimentos sociais.

No campo das políticas externas os países submetidos aos regimes militares comprometeram-se decisivamente com a diplomacia estadunidense, notadamente no que diz respeito ao isolamento de Cuba expulsa da Organização dos Estados Americanos (OEA) e submetida a um prolongado bloqueio econômico.

Nas suas políticas internas o Estado controlava a informação através de uma censura rigorosa aos meios de comunicação e a produção artística, práticas 
sustentadas, sobretudo, em intensas campanhas publicitárias que exaltavam os governos e segregavam os opositores.

A política de controle dos meios de comunicação produziu uma transformação significativa que levou alguns grupos à falência ao mesmo tempo em que consolidava grupos comprometidos com o projeto da ditadura. $\mathrm{O}$ resultado desse processo foi à formação de um número reduzido de conglomerados midiáticos que não só apoiaram os golpes de Estado, e deles se beneficiaram formando impérios de controle da informação. Essa condição se manteve após a redemocratização e segue inalterada, até o presente.

Por outro lado, os aparelhos de coerção não estavam submetidos a limites legais que os impedissem de reprimir o que consideravam guerras internas. No caso do Brasil - sob a garantia das Leis do regime autoritário - tinham a certeza de que seus crimes náo seriam levados a julgamento e, ilusoriamente, permaneceriam esquecidos.

A violência do aparelho de coerção organizou-se como uma sólida política pública, altamente qualificada e autorizada. Tinha o respaldo dos generais comandantes do governo e contavam ainda com o apoio financeiro de grupos empresariais e de proprietários de terra.

Os golpes dos anos 1960-1970 puseram fim à breve experiência de soberania que a América de Sul e o Caribe ensaiavam desde o final da $2^{\circ}$. Guerra Mundial. Experiência que seria desmontada para suprimir os projetos nacionalistas. A dimensão das mudanças não ficaria restrita ao embate ideológico próprio da guerra, mas pelo uso indiscriminado da força que os novos regimes garantiriam seu poder. Ou como argumenta Eagleton "Não é, finalmente, infringindo direitos culturais, mas pela tortura, pelo poder das armas e pela morte que esses regimes salvaguardam seus privilégios" (EAGLETON, 2003, p. 144).

De forma semelhante, porém distinta da europeia, a juventude brasileira, a sul-americana e a caribenha moveram-se contra as ditaduras militares, contra a invasão cultural e o domínio econômico internacional. Os muros das universidades não só pediam o impossível, ao contrário, clamavam pelo fim da ditadura e pela expulsão do imperialismo, enquanto denunciavam as torturas, os sequestros e os assassinatos cometidos pela força bruta do terror do Estado.

No sul da América a minissaia, os sons e os cabelos longos da juventude europeia eram acompanhados pelas canções de protesto que convidavam a "passear na floresta escondida [...] passear na avenida” (VELOSO, 1968), e anunciavam que havia "[...] uma cordilheira sob o asfalto" (VELOSO, 1968), e pelas experiências de um teatro de vanguarda disposto a anunciar que mesmo sob o espectro do medo que 
carregava tudo para lugar nenhum ainda era possível querer "ter voz ativa, no nosso destino mandar" (HOLANDA, 1968) ${ }^{1}$.

A vontade de assumir o próprio destino era contida pela roda viva da violência, tanto legal como a clandestina. $\mathrm{Na}$ condição de guerra interna imposta pelo Estado tornou-se urgente defender a vida dos inimigos do regime o que foi feito em nome dos direitos humanos a partir de alguns setores das Igrejas cristâs que se organizaram em torno das Comissões de Justiça e Paz (CJP) de alguns estados brasileiros ${ }^{2}$. Foi especialmente através das ações das Comissóes de Justiça e Paz e das organizações clandestinas que a sociedade brasileira soube dos covis, "dos passos no porão [...] da assombração e das almas com perfume de jasmim” (HOLANDA, 1977) ${ }^{3}$. Foi, também, por estas açóes que a sociedade civil iniciou seu processo de reorganização movida por objetivos específicos sempre vinculados aos princípios dos direitos humanos.

Naquele período histórico a sociedade civil considerava que ao ser eliminado toda forma de censura, o direito a liberdade de pensamento e de informação estariam assegurados. Ao mesmo tempo sonhava com o direito a liberdade de reunião, com a livre associação em sindicatos e partidos independentes do Estado. As liberdades de manifestação e de reunião são, desde a Declaração Francesa dos Direitos do Homem de 1789, pressupostos inalienáveis da democracia e se constituem em direitos civis

\footnotetext{
${ }^{1}$ A peça Roda Viva de Chico Buarque de Holanda. Sua estética estava vinculada ao chamado Teatro de participação originado pelo Teatro Opiniáo e o Teatro de Arena. Dirigida por José Celso Martinez Côrrea foi vista com desconfiança pelos críticos da época. Duas apresentações da peça - em julho de 1968 em São Paulo e em setembro do mesmo ano em Porto Alegre - foram interrompidas por um Grupo de extrema direita chamado Comando de Caça aos Comunistas que quebrou as casa de espetáculo, sequestrou e bateu nos atores e atrizes que compunham o elenco. A seguir a peça foi censurada e os sequestradores nunca foram submetidos a julgamento.

${ }^{2}$ A Comissão de Justiça e Paz de São Paulo coordenada pelo Cardeal D. Paulo Evaristo Arns constituiu-se num importante lugar de defesa da vida. Dela participaram intelectuais, lideranças operárias e estudantis (VIOLA, 2008).

${ }^{3}$ Recuperamos aqui toda a letra da música na medida em que usaremos outros versos da mesma ao longo do texto. Se lembra da fogueira - se lembra dos balóes - se lembra dos luares, dos sertóes - A roupa no varal, feriado nacional e as estrelas salpicadas nas cançóes - Se lembra quando toda modinha falava de amor - Pois nunca mais cantei, maninha, depois que ele chegou - Se lembra da jaqueira a fruta no capim - o sonho que você contou pra mim - Os passos no porão lembra da assombração e das almas com perfume de jasmim - Se lembra do jardim, oh maninha, coberto de flor - Pois hoje só dá erva daninha no chão que ele pisou - Se lembra do futuro que a gente combinou - Eu era tão criança e ainda sou - Querendo acreditar que o dia vai raiar Só porque uma cantiga anunciou - Mas não me deixe assim tão sozinho a me torturar - que um dia ele vai embora, maninha pra nunca mais voltar.
} 
fundamentais, tanto como cultura cívica, quanto para as instituições do Estado e o caráter democrático dos regimes políticos.

A luta pelas liberdades de informação, de manifestação de pensamento e de associação foram seguidas pela pressão crescente por eleiçôes livres tornadas possíveis pelo crescimento eleitoral (tanto nas eleiçóes municipais e regionais, quanto nas parlamentares) do partido de oposiçáo, o Movimento Democrático Brasileiro (MDB). Ao mesmo tempo em que os movimentos sociais se multiplicavam e assumiam reivindicações por direitos sociais e econômicos.

Aos poucos e timidamente o movimento social, aliado com os setores do Estado que haviam sido conquistados pelo $\mathrm{MDB}$, ousou propor eleiçóes diretas considerando que a democracia estivesse assegurada na medida em que a cidadania fosse garantida pelo direito do voto (BOBBIO, 1992). Até esta ocasião, na conjuntura ditatorial, as ruas e as praças haviam sido tomadas por uma cidadania ansiosa para projetar a esperança coletiva de que nunca mais a barbárie tivesse lugar na sociedade brasileira e latino-americana.

Mesmo que a reivindicação da democracia estivesse contida aos processos eleitorais, para aqueles que detinham o poder, a democracia representativa equivalia a uma ameaça revolucionária comparável as contestações, chamadas de subversivas, dos anos 1960/1970. Apesar das numerosas manifestações de rua em torno da campanha pelas Diretas-Já, foi preciso esperar ainda alguns anos para a primeira eleição direta. O primeiro presidente civil, ainda foi guindado ao poder nos moldes das eleiçóes do ciclo militar.

A democracia representativa foi, em parte, uma reação consciente e possível das razões práticas de continuidade que vivia a sociedade brasileira. Significava eleição aberta de representantes e a garantia de alguns direitos políticos, entre eles, a liberdade de expressão, que mantinha o caráter aberto da discussão política. Através dela a sociedade civil reconhecia que os direitos humanos são inerentes a democracia e que a democracia corresponde à vigência dos direitos humanos não só aceitos pelo Estado, mas por ele implantados (BOBBIO, 1992).

O passo seguinte para a democratização ocorreu através da campanha por uma constituinte livre e soberana. A razão prática da transição lenta e gradual impôs uma constituinte parlamentar levando os movimentos sociais a elaborar emendas populares referendadas por assinaturas da sociedade civil e recolhidas nos lugares públicos das cidades brasileiras.

A Constituinte produziu uma legislação que incorporou os princípios fundamentais dos direitos humanos - como cláusula pétrea - definindo prazos (alguns deles ainda esperam para serem regulamentados) para concluir a transição do 
autoritarismo para a democracia plena. De um lado a garantia dos princípios clássicos de tradição liberal, que incluem eleições livres, liberdade de expressão e de organização. De outro lado a Constituinte não se dispôs a rever o passado e preservou componentes jurídicos vindos do período autoritário.

Temas urgentes para a transição não foram regulamentados pela legislação que complementaria o trabalho da constituinte. Entre eles destacamos duas questóes que a nascente democracia não conseguiria superar:

1) A questão da anistia que ainda na ditadura militar incluiu, como sendo políticos, crimes contra a humanidade, por exemplo, os crimes de estupro, sequestro, assassinato e ocultação de cadáveres;

2) A mudança dos aparelhos de coerção, que mantiveram (e mantém) as mesmas estruturas, finalidades e modos de ação oriundos da doutrina de segurança nacional e da lógica de combate ao inimigo interno. No passado o "subversivo, terrorista e comunista", e hoje, o "vândalo, mascarado e anarquista”.

Foi a partir do reconhecimento dos direitos civis e políticos garantidos pela autodenominada Constituição Cidadã que os movimentos sociais - incluídos neles os movimentos da juventude - perceberam, ainda timidamente, que o Estado preservara heranças do passado autoritário e que a Constituinte não avançara o suficiente para superar as desigualdades sociais e econômicas de uma sociedade marcada por privilégios e preconceitos.

Ao longo da década de 1990 a sociedade democratizada acompanharia - um tanto surpresa - as transformaçóes sociais decorrentes das mudanças hegemônicas do capitalismo internacional. Experimentado ao longo da ditadura chilena (1973-1990) os princípios do novo liberalismo se tornaram hegemônicos na economia do continente latino-americano. Seus pressupostos insistiam que a economia é séria e eficiente e o social irresponsável e perdulário (RIBEIRO, 2000). Insistiam também que a liberdade do mercado é condição indispensável para o desenvolvimento e que o Estado deve se resumir a ser um bom gestor da coisa pública, e o ente que preserva o monopólio da violência (WEBER, 1998).

A nova ideologia, apoiada no pensamento único dos anos da Guerra Fria e fortalecido com o mito do fim da história, tentava refazer a leitura dos direitos humanos reduzindo o princípio da liberdade como sendo o direito do livre mercado, que o princípio da igualdade podia dissolver-se no reconhecimento das diferenças e, por fim, que o princípio da solidariedade devia ficar restrito a esfera dos indivíduos.

Sob as orientações do chamado Consenso de Washington o novo liberalismo serviu de plano de fundo para as mudanças na estrutura do Estado, especialmente 
com a política de privatizações de bens públicos e a liberalização econômica que priorizava os cortes de gastos sociais em detrimento das concessóes e financiamentos para o capital transnacional. Essas práticas fizeram crescer os índices de desigualdade, desemprego e violência, enquanto os já frágeis serviços de amparo social entravam em crescente esfacelamento e a estrutura social era submetida a transformaçóes profundas.

No início dos anos 1990 a juventude retornaria à cena política brasileira reocupando as ruas do país com os rostos pintados de verde amarelo. Para esses movimentos já não importava o comprimento dos cabelos e o tamanho das saias, mas sim tirar do poder um presidente reconhecidamente corrupto que havia sido eleito com a ajuda dos grandes meios de comunicação que passaram então a instigar a juventude a protestar. As músicas que ouviam, os filmes e as peças de teatro que assistiam já não passavam mais por censura. As notícias que recebiam continuavam sendo filtradas pelos conselhos editorias das empresas de comunicação que detinham o monopólio da informação e definiam o que transmitir e o que sonegar.

O presidente - pretenso herói como era tratado na campanha presidencial foi recusado pelos jovens que reocuparam as ruas das cidades, sendo deposto da presidência e tendo o mandato cassado segundo os ritos constitucionais.

Para além do fato que a sua deposição, e posterior sucessão, não houvessem colocado em risco a democracia política, como ocorrera na década de 1960, a sociedade brasileira começava a conviver com movimentos sociais que não se resumiam a dimensão de direitos civis e políticos. Esses movimentos acrescentavam às suas reivindicaçôes os direitos sociais e econômicos, bem como os direitos de ordem subjetiva, como o direito ao meio ambiente, a paz e ao controle da violência social. Especialmente da violência exercida pelo Estado contra os setores empobrecidos pelas políticas econômicas dos primeiros governos civis autoproclamadas de medidas revolucionárias do novo liberalismo.

As últimas décadas do século passado e os primeiros anos do ainda jovem século XXI apresentam cenários de um novo ciclo de participação da juventude. Trata-se de um ciclo que se caracteriza pela formação de sujeitos coletivos, que buscam formas participavas de organização e de tomadas de decisão, revelando uma inovadora capacidade de aproximar uma pluralidade de interesses em torno de bandeiras que não se limitam a mudanças na estrutura do Estado, mas que requerem a criação de formas - ainda inéditas na contemporaneidade - de democracia direta e plural.

Nesta direção, os movimentos da juventude retomam o caminho das manifestações sociais, se espalhando pela América Latina de forma muito semelhante 
ao que vem ocorrendo em outras partes do mundo. São movimentos em oposição direta as medidas de deteriorização dos direitos sociais e econômicos, direitos esses que foram anunciados na Constituição cidadã, mas relegados pelo Estado desde que este se submeteu a hegemonia do novo liberalismo.

Desde entấo a questáo social significa irresponsabilidade administrativa e uso irresponsável de recursos públicos. Os pressupostos do novo liberalismo náo só permitem recordar a primeira república $(1889$ - 1930), quando a questão social era tratada como uma questão de polícia, como a crise econômica mundial que foi publicamente anunciada em 2008 e colocou a economia em recessáo, aumentaram a crise social. Dela decorrem as manifestações das sociedades em busca de direitos e as pautas anunciadas pela geração de jovens da década de 1960 parece, agora, ganhar uma dimensão global.

\section{Não vos deixaremos dormir4}

A busca pela consolidação de uma cultura de direitos humanos e a efetivação dos anúncios feitos nas décadas passadas talvez possam ser apontados como os germens das manifestações e dos protestos que tomam as ruas das cidades brasileiras desde 2013. Essa busca, que também se traduz na luta pela efetivação dos direitos sociais e econômicos é posicionada, é considerada pelo novo liberalismo como uma herança da irresponsabilidade administrativa do Estado de Bem Estar. Dentre as demandas advindas das manifestações destacam-se as formas de participação, a superaçáo dos limites da democracia representativa e, não menos importante, a exigência do controle popular sobre os aparelhos de segurança do Estado.

Todos esses temas são indispensáveis para que se possa pensar a consolidação dos direitos humanos em qualquer sociedade. Contudo, são as práticas herdadas do período ditatorial que seguem atuais nos organismos e aparelhos de repressão do Estado que nos permitem estabelecer aproximações entre o passado e o presente. As demandas relembradas acima representam campos em disputa no processo de formação da democracia brasileira. Ainda fazem parte do rol de reivindicações dos movimentos sociais da juventude porque não foram assimiladas pelo aparelho de segurança. Ao contrário, nele ainda se faz presente os pressupostos teóricos e os modos de açáo do período da Doutrina de Segurança Nacional.

Como a história nos mostra através de diversos exemplos, não é exclusividade desse período histórico - muito menos uma novidade - que toda tentativa de mudança, questionamento ou ruptura frente aos privilégios de classe provoca a reação

4 "Se não nos deixam sonhar, não vos deixaremos dormir". Movimento 15-M, Espanha, 2011. 
dos setores sociais que sentem seus privilégios ameaçados, o que provoca, não raras vezes, o uso da coerção e da violência estatal.

A herança de muitas das formas de coerção da década de 1960 possibilita que frações dos atuais movimentos caracterizem a atual fase da democracia brasileira como um "Estado de exceção", na medida em que numa democracia o direito a livre manifestação está assegurado não só como um direito fundamental, mas como clausula pétrea da Constituição nacional.

As heranças do Estado autoritário não se resumem a ação dos organismos de repressão do Estado. Estão presentes também na esfera jurídica e em suas propostas de criminalizar os movimentos sociais por açóes supostamente terroristas, prática usual de setores do judiciário5. Para Castells (2013, p. 11) “[...] as relaçóes de poder são constitutivas da sociedade porque os que detêm o poder constroem as instituiçóes segundo seus valores e interesses".

É importante ter claro como se dão as relações e as disputas de poder na sociedade para que não se caia na armadilha de denominar ditadura o que é, de fato, herança autoritária. Essa herança está vinculada a criação de um imaginário social determinado. Através dele a grande mídia contribui para a manutenção dos privilégios históricos de parte seleta da sociedade brasileira e para a criação dos "vândalos, mascarados e arruaceiros" que, no século passado, eram os "subversivos e terroristas".

O que separa um tempo de outro, nesta questão, é que no passado os jornais de oposição circulavam de forma clandestina e seus redatores e leitores eram considerados como criminosos pela Lei de Segurança Nacional, enquanto no presente, as informaçóes são instantâneas e plurais, e os veículos alternativos de comunicação são múltiplos. Sua intensidade é de tal significado que chega a colocar em risco a hegemonia da mídia tradicional. Para Castells:

Coerção e intimidação, baseados no monopólio estatal da capacidade de exercer a violência, são mecanismos essenciais de imposição da vontade dos que controlam as instituiçóes da sociedade. Entretanto, a construção de significados na mente das pessoas é uma fonte de poder mais decisiva e estável. A forma como as pessoas pensam determina o destino de instituiçốes, normas e valores sobre os quais a sociedade é organizada. Poucos sistemas institucionais podem perdurar baseados unicamente na coerção. Torturar corpos é menos eficaz que moldar mentalidades. (CASTELLS, 2013, p. 11-12).

5 Basta recordar o recente episódio onde o Supremo Tribunal Federal (STF) negou a revisão solicitada pela Ordem dos Advogados do Brasil (OAB) - da Lei de Anistia. 
A ditadura militar - e seus herdeiros dos organismos de repressão de hoje soube se utilizar do potencial destrutivo da violência como forma de coerção e disciplina através das quais punia - e ainda pune - fisicamente o "subversivo" de ontem e o "vândalo" de hoje. Tanto no passado como no presente, o corpo é punido com rigor, seja na tortura dos poróes e viaturas, ou na rua, nos atos, protestos e manifestações. Porém, o papel da mídia corporativa não passa pelo suplício da dor física, sua atuação se dá na distorção das informações, na criação ilimitada de pretensas verdades e na produção de preconceitos e de medo que buscam incutir na sociedade. Para Castells (2013, p.11), "o poder é exercido por meio da coerção (o monopólio da violência, legítima ou não, pelo controle do Estado) e/ ou pela construção de significado na mente das pessoas, mediante mecanismos de manipulação simbólica”.

A divisão das manifestaçóes em "legítimas" ou "violentas", bem como dos manifestantes, entre "pacíficos" e "vândalos", cria um falso imaginário em setores da sociedade que, movidas pelo medo e o preconceito, passam a aceitar o uso da força e da violência sob os "maus manifestantes", de forma a garantir a "ordem" e punir os "vândalos".

Tanto hoje como ontem, os corpos dos manifestantes são punidos com rigor físico e vigilância pessoal. As corporações midiáticas selecionam imagens e textos enquanto escolhem rótulos e mensagens para os processos de construção simbólica que "[...] dependem amplamente das mensagens e estruturas criadas, formatadas e difundidas nas redes de comunicação multimídia” (CASTELLS, 2013, p. 12). Ultramoderna em suas tecnologias de informação, a mídia recupera o maniqueísmo medieval saudando os manifestantes bem comportados - pacíficos - e précondenando aqueles que não se enquadram nesta tipologia. Estes - os inadaptados são rotulados de "vândalos", são descritos como pertencentes a grupos extremistas de Black Blocs ${ }^{6}$ que se deve temer. Como no início do século passado, a mídia corporativa busca construir no imaginário da população a noçáo de que a questáo social é uma questão de polícia.

O que fica perdido na neblina produzida pelo manto da ideologia tecido pela mídia corporativa e hegemônica são as pautas reais que, sobretudo a juventude, tem levado às ruas. Sobre um conceito desfigurado de violência, a mídia e parcelas

\footnotetext{
${ }^{6}$ Black Bloc é uma tática de autodefesa adotada por um grupo de indivíduos para proteger a manifestação da repressão policial. É um grupo espontâneo e não um movimento organizado como a grande mídia repete incessantemente.
} 
significativas do corpo político/partidário deslocam o foco dos protestos para as depredações.

Os críticos das manifestaçóes não se perguntam quais seriam as suas origens ou quais os processos históricos que originaram os atos resultantes das manifestaçóes. Não percebem o quanto esses atos podem simbolizar a falta de expectativas no futuro, a inexistência de direitos prometidos, a recusa dos sonhos anunciados pelo acesso ilimitado as maravilhas do mercado livre.

Foucault destaca ironicamente que: “[...] as leis são boas, para os pobres; infelizmente os pobres escapam às leis, o que é realmente detestável. Os ricos também escapam às leis, porém isso não tem importância alguma, pois as leis não foram feitas para eles." (FOUCAULT, 2003, p. 94). Sobre o papel da penalidade e das leis Foucault (2003, p. 99) lembra que:

[...] Essa ideia de uma penalidade que procura corrigir aprisionando é uma ideia policial, nascida paralelamente à justiça, fora da justiça, em uma prática dos controles sociais ou em um sistema de trocas entre a demanda do grupo e o exercício do poder (FOUCAULT, 2003, p. 99).

A juventude que retoma as ruas e confronta o aparato repressivo mesmo ao preço de perseguiçóes infames e inquéritos forjados dignos de filmes hollywoodianos que serviram a ideologia da guerra fria faz, mais uma vez - talvez sem perceber - uma ruptura com o mito do povo cordial, pacato, ordeiro, dócil e pacífico ${ }^{7}$. Esse homem cordial que nunca existiu a não ser no imaginário das elites nacionais, desaparece de vez em episódios como a Cabanagem, a Balaiada, em Canudos ou no Araguaia.

Antes mesmo dos movimentos de 2013 questionarem indiretamente o mito do homem cordial, este mito já estava destruído pelas desiguais condições de vida de cada um dos setores sociais contemporâneos. Essa desigualdade que coloca em dúvida a afirmação de que somos todos sujeitos de direitos. Desigualdade que provoca tensões cotidianas que se manifestam em múltiplos lugares do espaço urbano no qual vive a maioria dos jovens de agora e que se agudizam quando pensamos nas condiçóes materiais "dos espaços de moradia, lazer e trabalho nas cidades brasileiras" (CARRANO, 2008, p. 189).

${ }^{7}$ Estamos partindo da reflexáo suscitada pela obra de Sérgio Buarque de Holanda (1995), "Raízes do Brasil". 
Condições que se aproximam, quando não confirmam, o que Agamben (2010) denominou de "vida nua" e que colocam em dúvida a possibilidade do Estado para agir como promotor de direitos e que se agrava, segundo Carrano (2008):

[...] pela força do mercado na produção de necessidades e sentidos culturais, o descrédito das instituiçóes e atores tradicionais (escolas, partidos, sindicatos, igrejas, etc.), a globalização, a força dos meios de comunicação e as conexóes perversas promovidas pelas redes do crime e da droga (CARRANO, 2008, p. 187).

As transformaçóes que o desenvolvimento econômico produziu trouxeram significativas mudanças ao mundo contemporâneo. Impulsionado por amplos investimentos privados desencadeados pelo mercado mundial, o capitalismo realizou importantes transformaçóes tecnológicas alterando as formas de produção e a própria compreensão das cidades e dos lugares da vida cotidiana. Estas transformaçóes alteraram também as possibilidades de relaçôes humanas e as subjetividades da vida individual e coletiva. Modificaram-se - nesta nova condição material e subjetiva - as relações sociais e de comunicação entre as pessoas. As cidades passaram a não ser espaços de criação e ocupação humanas, de produção econômica e realizaçóes culturais. Transformaram-se em "lugares onde ocorrem fenômenos expressivos que entram em tensão com as pretensóes dominantes de racionalização da vida" (CARRANO, 2008, p. 188).

Os movimentos sociais dos jovens têm se beneficiado destas transformações não só para convocar suas manifestações, mas também para produzir novas formas de comunicação que obrigam a mídia corporativa a se reinventar na medida em que suas reportagens, seus editoriais e seus formadores de opinião passam a se deparar com novas formas de comunicação geradas no momento em que as manifestações acontecem. Com sua credibilidade colocada em risco, a mídia corporativa começa a abandonar sua aparente neutralidade e recupera sua fábrica de preconceitos contra os manifestantes. Agora sem sofrer a censura do Estado como ocorria nas décadas de 1960 a 1980.

As manifestações que percorrem as ruas das principais cidades do planeta e que no Brasil percorreram o país em meados de 2013 têm demonstrado que os jovens

\footnotetext{
${ }^{8}$ Este é um dos principais conceitos trabalhados por Agamben e não temos espaço para desenvolvê-lo amplamente. No tocante a este texto estamos trabalhando o conceito como a negação de proteção (social, econômica, jurídica, etc.) a aqueles que não se submetem à ordem tal como é imposta pelas estruturas de poder dominante. Entenda-se que a "vida nua" aqui é utilizada para simbolizar uma condiçãa de "exceção permanente".
} 
retomam as lutas em defesa do direito à liberdade de informação. Ao mesmo tempo, denunciam o controle feito pelo monopólio dos meios de comunicação e as tentativas de cerceamento de participação em curso nas diferentes sedes dos Parlamentos nacionais, desenvolvendo novas formas de comunicação através do uso das tecnologias de comunicação cada dia mais facilmente disponíveis. Essa tecnologia que inicialmente era o "feitiço" mercantil e deveria funcionar como diversão alienadora acabou "se virando contra o feiticeiro" e converteu alienação em ação.

As manifestações e protestos que tem tomado às ruas do país parecem estar percorrendo um caminho diferente dos movimentos que os antecederam. Sobre os signos que contemplam a diversidade e a ambivalência de uma juventude que percebe e interage com a realidade sob as telas da tecnologia digital estáo ideais transgeracionais de luta por autodeterminação, equidade, justiça, que podem ser descritos na forma de uma cultura de direitos humanos. Essa lógica de questionamento ao poder vem buscando formas de resistência que não obedecem, necessariamente, a receitas prontas. Como nos lembra Castells (2013, p. 25) "Além disso, devem acionar a conexáo entre diferentes redes de mudança social, por exemplo, entre redes pró-democracia e redes pela justiça econômica, redes voltadas para os direitos das mulheres, a conservação ambiental, a paz, [e] a liberdade [...]". Do mesmo modo produz uma nova cultura que não necessita de líderes inquestionáveis.

\section{Considerações}

As transformaçóes trazidas pelo desenvolvimento econômico produziram significativas mudanças no mundo contemporâneo que não se resumiram aos meios de comunicação. Impulsionado por amplos investimentos privados possibilitados pelo mercado mundial as inovações tecnológicas do capitalismo alteraram não só as formas de produção, mas a própria compreensão das cidades e dos lugares da vida cotidiana. Mudanças que alteraram também as possibilidades de relaçóes humanas e as subjetividades da vida individual e coletiva. Modificaram-se, nesta nova condição material e subjetiva, as contradiçóes no interior das relaçóes sociais e de comunicação entre as pessoas. As cidades passaram a ser não só espaços de criação e ocupação humanas e de produçáo econômica e realizaçóes culturais, mas constituíram-se também em "lugares onde ocorrem fenômenos expressivos que entram em tensão com as pretensões dominantes de racionalização da vida" (CARRANO, 2008, p.188).

$\mathrm{O}$ universo das mudanças no qual vive a sociedade de hoje marca a juventude e a coloca em movimento. Um movimento plural, como é plural a condição de vida dos jovens que transitam hoje para a vida adulta. Transição radicalmente diferente 
daquela vivida nas décadas de 1960-1980. Os jovens de agora não são os mesmos e nem todos vivem como os seus pais viviam?. Se a constituição, herdeira das lutas por direitos civis e políticos, lhes garante liberdades formais, não pode garantir a igualdade social e nem mesmo a fraternidade entre as classes, talvez uma fraternidade impossível se deixada por conta do mercado livre ou a cargo de um sistema econômico que, para sua sobrevivência, necessita acumulação permanente.

As contradiçôes entre as promessas de direitos humanos e sua efetividade, as diferenças sociais intensas e que não cessam de se ampliar e os preconceitos históricos que geram discriminação contra raças, gêneros e condição social são compreendidas pelos jovens que as denúncias em cartazes e cantos pelas ruas das cidades. Outra vez, receosos das mudanças pretendidas pelos jovens - mas não só por eles - os setores sociais historicamente beneficiados se colocam em movimento para preservar seus privilégios historicamente arraigados e recusar - uma vez mais - os direitos universais.

A manipulação midiática vem acompanhada das medidas "legais" que os setores do poder político, comprometidos com os privilégios das elites - e também por isso dominante - levam a efeito para garantir o status quo. Além das leis que proibiram os manifestantes de cobrirem o rosto ${ }^{10}$ durante as manifestaçóes e das tentativas de tipificar a organização popular como "formação de quadrilha", está em tramitação no Congresso Nacional o projeto de Lei 728/2001 (BRASIL, 2011) que tipifica o crime de terrorismo no Brasil. Esse projeto de lei prevê penas de 15 a 30 anos de prisão, cumpridas em regime fechado, de forma inafiançável, para quem praticar atos considerados "terroristas".

A pressa em aprovar a criminalização dos movimentos não se faz presente no Parlamento quando se trata de legislar sobre questóes sociais. Se o que está em curso, em setores do poder Judiciário, seguir as práticas dos tribunais militares do século passado poderemos reproduzir inquéritos que neguem os direitos civis e políticos pelos quais a sociedade brasileira se mobilizou ao longo de sua história.

\footnotetext{
${ }^{9}$ No original o verso do compositor cearense Belchior (1976), na música Como Nossos Pais, tinha a seguinte redação "Apesar de termos feito tudo o que fizemos ainda somos os mesmos e vivemos como os nossos pais".

${ }^{10}$ Quando a resposta a violência perpetrada pela polícia se radicalizou e grupos de autodefesa adotaram a tática Black Bloc, as autoridades não tardaram em criar formas "legais" de proibir que os manifestantes cobrissem o rosto e dificultassem a sua identificação. Começou no Rio de Janeiro com um lei proibitória sendo votada em regime de urgência pela Assembleia Legislativa. Logo foi a vez de São Paulo, Brasília e Porto Alegre. E em semanas as principais capitais e cidades do país já contavam com leis semelhantes que proibiam os manifestantes de cobrirem o rosto durante protestos.
} 
O processo histórico tem demonstrado que os direitos humanos, dos jovens e de todos os setores sociais, são conquistas que o movimento social impõe aos Estados nacionais e aos privilegiados de todos os tempos. Estes setores náo precisam - e historicamente nunca precisaram - de direitos e da democracia, pois quando tem seus privilégios ameaçados não temem em recorrer aos meios necessários - entre eles a violência e a manipulação das informaçóes - para seguir garantindo a sua condição. Seria ingênuo pensar que o pensamento autoritário pudesse um dia ir "embora para nunca mais voltar” (HOLANDA, 1977) quando o que está em jogo é a construção de uma democracia plena, entendida como sinônimo de uma cultura de direitos humanos.

- Solon Eduardo Annes Viola é professor do Programa de PósGraduação em Ciências Sociais da Universidade do Vale do Rio dos Sinos. E-mail: solonv@unisinos.br.

- Thiago Vieira Pires é mestrando em Ciências Sociais pela Universidade do Vale do Rio dos Sinos e bolsista PROSUP/CAPES. E-mail: thiago.v.pires@gmail.com.

\section{Referências}

ADORNO, Theodor W. Educação e Emancipação. São Paulo: Editora Paz e Terra, 2010.

AGAMBEN, Giorgio. Homo Sacer: o poder soberano e a vida nua I. 2a Ed. Belo Horizonte, MG: Editora UFMG, 2010.

BELCHIOR. Como Nossos Pais. In: Alucinação. Polygram, 1976.

BOBBIO, Norberto. A Era dos Direitos. 8a ed. Rio de Janeiro: Campus, 1992.

BOURDIEU, Pierre; PASSERRON, Jean C. A Reprodução: Elementos Para Uma Teoria do Sistema de Ensinos. Rio de Janeiro: Editora Francisco Alves, 1975.

BRASIL. 2011. Projeto de Lei do Senado No 728 de 2011. Define crimes e infraçóes administrativas com vistas a incrementar a segurança da Copa das Confederaçôes FIFA de 2013 e da Copa do Mundo de Futebol de 2014, além de prever o incidente de celeridade processual e medidas cautelares específicas, bem como disciplinar o direito de greve no período que antecede e durante a realização dos eventos, entre outras providências. Disponível em: <http:/www.senado.gov.br/atividade/materia/detalhes.asp?p_cod_mate=103652>. Acesso em: 10 jan. 2014.

CARRANO, Paulo. Identidades Culturais Juvenis: Arenas de Conflitos e Possibilidades. In: MOREIRA, Antônio F.; CANDAU, Vera M. (Orgs). Multiculturalismo Diferenças culturais e Práticas Pedagógicas. Petrópolis, RJ: Editora Vozes, 2008. 
CASTELLS, Manuel. Redes de indignação e esperança: Movimentos sociais na era da internet. Rio de Janeiro, RJ: Zahar, 2013.

CHOMSKY, Noam. Contendo a Democracia. Rio de Janeiro: Editora Record, 2003.

EAGLETON, Terry. A ideia de Cultura. São Paulo: Ed. Unesp. 2003.

FOUCAULT, Michel. A verdade e as formas juridicas. $3^{\text {a }}$ Ed. Rio de Janeiro, RJ: NAU, 2003.

HOLANDA, Chico Buarque. Roda Viva. In: . Chico Buarque de Holanda Volume 3. Som Livre, 1968.

HOLANDA, Chico Buarque. Maninha. In: Miúcha e Antônio Carlos Jobim. RCA. 1977.

HOLANDA, Sérgio Buarque de. Raízes do Brasiı. 26 Ed. São Paulo, SP: Companhia das Letras, 1995.

RIBEIRO, Renato J. A Sociedade Contra o Social: o Alto Custo da Vida Pública no Brasil. São Paulo: Companhia das Letras, 2000.

VELOSO, Caetano. Alegria Alegria. In: Caetano Veloso. Polygram, 1966.

VELOSO, Caetano. Enquanto Seu Lobo Não Vem. In: Tropicália. Polygram, 1968.

VIOLA, Solon E. A. Direitos Humanos e Democracia no Brasiı. São Leopoldo, RS: Ed. Unisinos, 2008. WEBER, Max. Economia y sociedade. Cidade do México: Fondo de Cultura Económica, 1998. 